\title{
Nature Based Solutions for Urban Resilience: A Distinction Between No-Tech, Low-Tech and High-Tech Solutions
}

\author{
Robbert PH Snep ${ }^{1 *}$, Joris GWF Voeten ${ }^{2}$, Gerben $\mathrm{Mol}^{3}$ and Tim Van Hattum ${ }^{1}$ \\ ${ }^{1}$ Wageningen University and Research, Wageningen, Netherlands, ${ }^{2}$ Urban Roofscapes, Amsterdam, Netherlands, \\ ${ }^{3}$ Amsterdam Institute for Advanced Metropolitan Solutions, Amsterdam, Netherlands
}

OPEN ACCESS

Edited by:

Dagmar Haase,

Humboldt University of

Berlin, Germany

Reviewed by:

Elzbieta Antczak,

University of Łódz, Poland

Olaf Schroth,

Weihenstephan-Triesdorf University of Applied Sciences, Germany

*Correspondence:

Robbert PH Snep

robbert.snep@wur.nl

Specialty section:

This article was submitted to

Land Use Dynamics,

a section of the journal

Frontiers in Environmental Science

Received: 26 August 2020 Accepted: 23 November 2020

Published: 18 December 2020

Citation:

Snep RPH, Voeten JGWF, Mol G and Van Hattum T (2020) Nature Based

Solutions for Urban Resilience: $A$ Distinction Between No-Tech, Low-Tech and High-Tech Solutions.

Front. Environ. Sci. 8:599060.

doi: 10.3389/fenvs.2020.599060
Urbanization and extreme weather require smarter urban water management. Nature-based solutions (NBS) like vegetated roofs and city trees can contribute effectively to climate resilience and future proof urban water management. However, large scale implementation is limited due to a lack of knowledge among professionals on how to capture, store, and reuse water on-site. In this paper we advocate a classification into no-tech, low-tech, and high-tech green, thereby supporting urban designers to better utilize the ability of these green elements to effectively manage water flows in different urban settings. Here, "no tech" green is considered traditional urban green, handling (rain) water like nature would. "Low-tech" green (e.g., extensive Sedum roofs) are suitable for dense urban settings with limited demand for water management and ecosystem services. More developed "high-tech" green solutions have vegetation performing even beyond natural capacities, offering full water management control options and enable city planners, architects and landscape designers to enhance urban resilience and circularity without claiming valuable urban space. We elaborate our "tech NBS" approach for city trees and vegetated roofs thereby demonstrating the classification's added value for sustainable urban design. We conclude that specifying the demanded "no/low/high" -tech level of green infrastructure in urban design plans will help to yield the most of ecosystem services using appropriate levels of available technology.

Keywords: nature based solutions, water smart cities, high tech, resilient cities, city trees, green cities, climate adaptation, green roofs

\section{INTRODUCTION: VEGETATED ROOFS AND CITY TREES AS OPPORTUNITY TO ACHIEVE WATER SMART CITIES}

Water is essential for life in cities: drinking water, hygiene, irrigation of green infrastructure and to some extend food production. Cities around the world face many challenges with water such as floods, water scarcity and water pollution (e.g., McDonald and Shemie, 2014; Mekonnen and Hoekstra, 2016; Urban Climate Change Research Network, 2018). On top of these challenges climate change will impact cities with more weather extremes such as droughts, excess precipitation, and heat waves. Further urbanization and need for climate adaptation enlarge the demand for functional urban green space, whereas at the same time plant and tree functionality, survival and growth is hindered by increasing 
heat, water shortages, and urban floods. Cities worldwide need to rethink and redesign cities toward water smart cities to deal with these challenges: from drained cities to cities that retain rainwater, use reclaimed (waste) water and only as final option drain excess water while creating opportunities to green the city and to increase livability (Brown et al., 2009; Van de Ven et al., 2016). More and more cities thereby consider nature-based solutions (NBS) - originally coined by MacKinnon et al. (2008) an integral part of their water management plans (Depietri and McPhearson, 2017). NBS tend to be more resilient to water stress than human engineered infrastructure because of their inherent enhanced resilience.

Central to NBS is the fact that they make use of natural alternatives to purely technological solutions in order to solve a wide array of problems. These NBS support ecosystem functions like enhancing biodiversity, water retention, reducing urban heat, increasing human health and wellbeing and the sustainable production of food. Often engineering is needed to create a reliable interface between the vegetation and the city to ensure that both can perform without hindering each other. There are numerous publications listing and quantifying urban NBS benefits (Eggermont et al., 2015; Hartig and Kahn, 2016; Kabisch et al., 2016; Nesshöver et al., 2016; Lafortezza et al., 2017; Bai et al., 2018; Parker and Simpson, 2018). These days, one could say the term "Nature-Based Solution" has been branded extensively and policymakers and practitioners address NBS as an alternative for traditional civil engineering (Faivre et al., 2017; Maes and Jacobs, 2017; Nikolaidis et al., 2017). However, mainstreaming NBS in city development practice often gets stuck at project level because only costs are recognized, financial benefits remain unaccredited, a clear evidence base for the benefits of NBS often lacks and high-tech solutions are evaluated according to old-tech or no-tech criteria (see a.o. Lafortezza et al., 2017; Bai et al., 2018). Or, as Davies and Lafortezza (2019) put it clearly "NBS can provide the focus and immediacy for decision makers to consider green infrastructure as serious alternatives." We therefore think there is momentum now to go beyond the current general term NBS and make a practical distinction based upon application value (where in the city to use which type of NBS?) and water management performance in terms of rainwater catchment, retention and re-use (what can we expect from the NBS?).

The aim of this paper is to outline our way of thinking about specifying city trees and vegetated roof systems (defining no-tech, low-tech and high-tech green) and to demonstrate the added value of such classification for the actual implementation into sustainable city practice. With a focus on these two urban green elements we thereby contribute to the increasing NBS-literature by discussing the technology aspect in relation to the NBS performance in urban water management and the NBS application in urban planning and design (Hansen et al., 2015). By adding this perspective, we hope to contribute to a better and more evidence-based application of NBS in city practice and remove barriers for NBS implementation among urban development professionals.

\section{CURRENT BARRIERS FOR NBS APPLICATION IN URBAN DEVELOPMENT PRACTICE}

Urban development is the process in which ambitions and plans for city development are translated into actual city building and construction, via several steps including design, tendering, contracting and construction. Depending on scale and complexity of the urban development a whole range of urban development professionals is included, and numerous legal and other procedures have to be taken into account.

To embed Nature-Based Solutions like vegetated roofs and city trees in urban development practice, it is critical that already in the early stages of planning and design NBS are considered a serious alternative for regular civil engineering (Van de Ven et al., 2016; Frantzeskaki, 2019). However, throughout the world we see a similar way of how NBS are treated, although the actual local process may differ. In several countries implementing NBS like green roofs has become a legal obligation for property owners (Basel, Switserland; Toronto, Canada; Portland, Oregon, USA-Greenroofs.com, 2019), or is being promoted via subsidies (Amsterdam, the Netherlands). There is a tendency among local authorities to regard the "installation of vegetation" as the real NBS achievement rather than the actual performance of NBS for climate adaptation and other functions. Example: some cities now present the hundreds of ha's of realized (mostly Sedum) green roofs as a success story. It seems that local actors assume that by implementing green roofs all potential ecosystem services and benefits are "delivered," independent of the type of vegetated roof system used. Research in Dutch cities has already demonstrated that the level of ecosystem performance, provided by different vegetated roof systems, varies greatly depending on used materials, soils, water management systems and vegetation types (Solcerova et al., 2017; Cirkel et al., 2018). "To vegetate or not to vegetate" is no longer just the question; the actual performance of NBS should be discussed, characterized and rewarded (Dorst et al., 2019). A similar outdated binary approach is observed with other NBS like city trees (e.g., OneMillionTrees initiative New York...numbers count!) and urban greenspace in general (e.g., European Green Capital, 2019).

One could say that these NBS are implemented in city practice, apparently without a clear understanding of the actual level of ecosystem performance for the local situation. However, effectiveness and added value are aspects not to underestimate, as one day we can expect a more indepth (societal) discussion on its cost-effectiveness (Pataki et al., 2011; Eggermont et al., 2015; Kabisch et al., 2016; Nesshöver et al., 2016; Lafortezza et al., 2017; Bai et al., 2018; Parker and Simpson, 2018). Another argument for addressing NBS performance: in the planning phase of projects sustainability goals-formulated by customers and/or the (landscape) architects-get incorporated in technical designs using high performance systems, creating reliable and climate proof solutions (Mussinelli et al., 2018). In the functional and technical description of the project however, the actual 
performance these systems have to deliver is not described or stipulated clearly enough, allowing contractors to propose, purchase and incorporate cheaper, low-performance solutions in the procurement and construction phase. Examples exist where water-retention was required in the building permit and only detention was realized in the final project, without the customer or the city officials even recognizing or identifying this performance gap.

If planning, contracting, design and/or construction professionals are not convinced that NBS offer valuable, necessary and competitive features, they will opt for the familiar solution-in most cases being a non-natural one. For the majority of urban development professionals not experienced with NBS it is hard to make a distinction between different NBS types and performance attributes (Wong et al., 2005). With the current fast technological succession of available systems, clarity in concepts and definitions becomes paramount. A vegetated roof system can be for example be a conventional green roof, a stormwater managing blue-green roof or an accessible roof garden. "A green roof is a green roof" is no longer valid since investments and ecosystem services provided by the different systems can differ greatly.

To support a better acceptance and large-scale accelerated implementation of NBS like vegetated roofs and city trees in city practice and to prevent high performance systems being replaced with low performance systems during the engineering and construction phase, we here argue to make a clear classification of these NBS based upon both its application area in the city and its performance in supporting climate resilience.

\section{CLASSIFYING VEGETATED ROOFS AND CITY TREES INTO "NO TECH, LOW-TECH OR HIGH-TECH" TO ACCELERATE IMPLEMENTATION}

If we want urban development professionals, property owners and investors to better value vegetated roofs and city trees in the process of (re)building cities, it is important to define a classification and accompanying criteria that are understandable and easy to apply. In the scientific literature this need for classification can be recognized because various authors propose typologies or classifications of these and other NBS based on different perspectives. Pataki et al. (2011) propose a framework that makes explicit use of the biogeochemical processes that are the foundation for ecosystem services such as greenhouse gas emissions, urban water runoff and pollution, and air quality and human health. From this perspective they attempt to assess the ecosystem services, possible disservices (negative consequences) and the net effectiveness of green solutions in a quantitative way. Kabisch et al. (2016) derive potential indicators for the effectiveness of NBS based on their integrated environmental performance, their effect on health and wellbeing, their transferability or upscaling potential, and their potential for citizen involvement. As a final example we mention the typology proposed by Eggermont et al. (2015) based on the criteria "amount of engineering needed" and "number of ecosystem services and stakeholder groups targeted."

From the viewpoint of the urban development sector the location and zoning status of the project is a clear fact: one knows in what type of urban context the planned (re)development will take place, and what the type of the development will be like (e.g., high-rise buildings in the city center, low density residential district in a suburb etc.). Our first criterion to define the type of demanded vegetated roof or city trees is whether the project will take place in dense urban settings or not. Below we will explain how this criterion matches with our suggested classification of these NBS into "no tech" vs. "low/high tech." A second criterion to define the type of demanded vegetated roof or city trees is whether water sensitive design is a serious priority in the project. With fast increasing global awareness on the impact of climate change there is a growing tendency to formulate climate adaptation targets for urban development projects. From this perspective the ability of certain vegetated roof or city trees to absorb, reduce or regulate water flows becomes more and more important. Below we elaborate how for dense urban settings this matches with our classification of these NBS into "low tech" vs. "high tech." We build our argumentation for the two criteria on the two parts of the NBS term, being "nature-based" (what to expect from nature, in terms of functioning and required space?) and "solution" (what to expect in terms of solving societal issues?).

\section{Urban Density and Levels of Technology}

Cities comprise the urban matrix and its green infrastructure. In the urban matrix, housing, road infrastructure and businesses have specific elements such as hardscapes, buildings and underground utilities that obstruct the natural functioning of the local ecosystem. The denser the urban location, the more the natural situation is being altered. Dense urban areas are also the places where the impacts of weather extremes such as floods, droughts, and heat waves are the largest (Skinner, 2006). For vegetation to be able to flourish and function in such settings, favorable growing conditions pertaining to rootable soil volume, water retention and drainage have to be incorporated and created (Cascone et al., 2018). We here define dense urban settings as that part of the urban matrix where specific technology is needed to make vegetation grow. Technology is considered here as supportive materials and installations, like customized treeor green roof soils, drainage and/or aeration systems, waterproof liners, retention units, and electronic water level controls (Sutton, 2015). Urban green space without such technology, where the vegetated surfaces are capable of intercepting, draining, and evaporating water like a natural situation for that location, such as open parklands, are considered "no tech" and can primarily be found in the city's main green infrastructure or in the low-density part of the urban matrix. Vegetated roofs always demand technology to protect the building and are therefore not considered "no tech." Vegetated roof systems and city trees depending on mentioned technology are considered "low or high tech" and can primarily be found in the high-density parts of the urban matrix. 


\section{Water Management and Levels of Technology}

An increasingly urgent question: can (rain)water be regulated effectively in cities? By better matching supply and demand and by retaining rainwater as resource, closing the water cycle in cities, such regulation ability becomes reality (Hattum et al., 2016). Rainwater can be captured and stored with on-site retention systems, and "harvested" as source for household sanitation, used for cooling cities through plant transpiration, or for recharging ground water levels to avoid drought damage. These man-made vegetated systems can regulate (rain)water effectively, because the growing site is designed for such performance. By improving and upgrading soil conditions, and adding additional engineering solutions like retention, capillary irrigation and water level sensing and controls, vegetated roofs boost improved water retention and detention during peak rain events and will continue to cool the urban environment for a longer period of time with retained rainwater during prolonged dry spells (Cirkel et al., 2018).

Low-tech vegetated roofs and city trees are capable of intercepting, draining and evaporating water like nature, but designed in such a fashion that they can only temporarily store extra water for later passive infiltration, drainage or irrigation in the body of soil available. They serve the function of natural green space with improved rainwater management, often for an area larger than the vegetated surface itself.

High tech vegetated roofs and city trees are capable of capturing, storing and re-using precipitation, on-site. Their design incorporates an open, high-strength, geocellular structure underneath the soil, allowing for measurable supplemental water retention. The system provides a controllable retention capacity up to $140 \mathrm{~mm}$ and uses natural capillary irrigation to return water to the soil during droughts. The system can be made dynamic, with sensor driven valve controls, which actively manage water levels through incoming and outgoing water flows. These systems minimize potential overflow into sewer systems during peak rain events while reducing mains-water needs for irrigation during times of drought. High tech vegetated roofs and city trees are at the core of harvesting rainwater not just for later plant irrigation but also for other functions such as toilet flushing, in such a fashion that these functions can be realized from the start, or easily added at a later stage without rebuilding the system. These systems often function invisibly and independent of land use on top of the system. They serve multiple purposes and truly fit the concept of the multifunctional layered city.

Figure 1 shows how one could decide which vegetated roof and city tree type is demanded for which project, Table 1 shows the characteristic details of the accompanying no/low/high-tech types.

We illustrate the different types of NBS with a brief description of the case Orly Square (low tech NBS) and IJburg Island (high tech NBS), both located in Amsterdam. Orly Square: in 2015 the City of Amsterdam realized the roof-park Orlysquare at the location of the former bus-station on top of train station Sloterdijk. Orly Square is now a public park with a mix of flowering perennial plants, bulbs and shrubs (Figure 2). The design creates an added $60 \mathrm{~mm}$ stormwater buffer in the $85 \mathrm{~mm}$

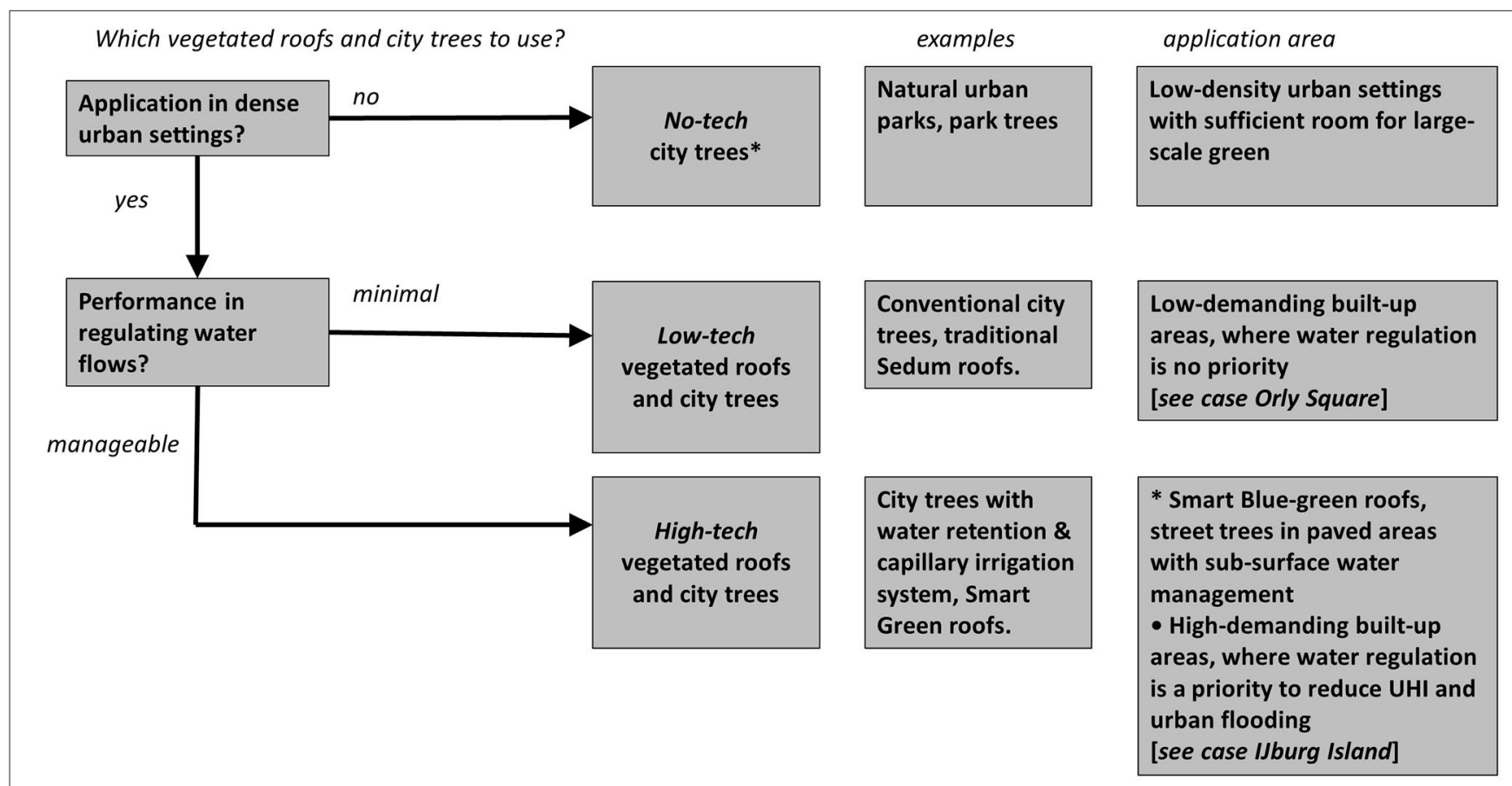

FIGURE 1 | Scheme to support urban designers in choosing the right type of vegetated roof and city trees for the right city location and purpose. Examples and application area per type are given, cases are described briefly in this article. ${ }^{*}$ There is no such as no-tech vegetated roofs. 
TABLE 1 | General water handling characteristics of no tech, low tech and high tech city trees and vegetated roofs.

\begin{tabular}{lll}
\hline No-tech & Low-tech & High-tech \\
\hline City trees and vegetated roof systems &
\end{tabular}

\section{General characteristics}

Description

Water functions

Water flow and level

management

Water sources

\section{City trees}

Cross section

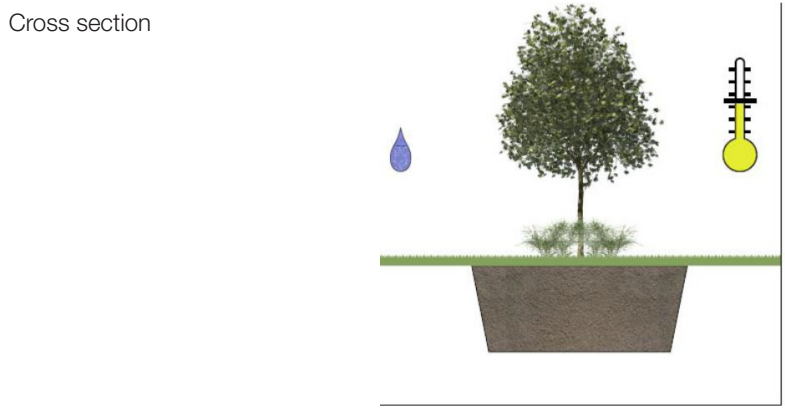

Description

Precipitation surface water handling

Surplus rainwater retention/detention

Climate change mitigation effect

Drought resilience

Vegetated roof systems

Cross section

Normal; natural water retention in soil profile
All natural and vegetated surfaces, capable of intercepting, draining and evaporating water like the natural situation for that location

Natural

Infiltration and evapotranspiration

No

Rain
A vegetated surface, capable of intercepting, draining and evaporating precipitation for that area and its direct surroundings, designed so that it can detain water for later infiltration and/or off-site drainage

\section{Passive}

Infiltration, limited detention and evapotranspiration

Determined by design

Rain and adjacent surfaces
A man-made vegetated or hardscaped system, capable of capturing, retaining and re-using precipitation for that area and its surroundings, characterized by on-site and dynamic water management

Active

Detention, retention, reuse and evapotranspiration

Adjustable, sensor- and valve controlled, dynamic

Rain, adjacent surfaces and roofs, mains water, HVAC condensate, TSE

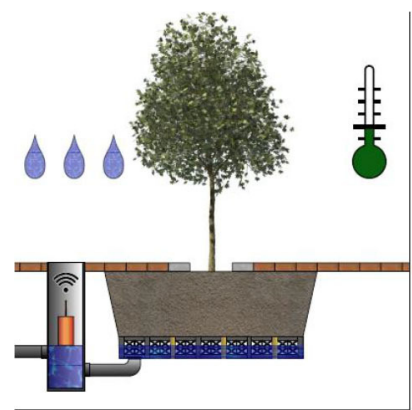

Tree in 100\% hardscape with geocellular water retention and capillary irrigation system in subbase

run-off designed toward the vegetated tree pit (e.g., rain garden)

Handles rainwater of adjacent paved area in the tree pit.

Detention for deep infiltration

Improved urban flood mitigation

Limited; due to draining nature of design

Handles rainwater from adjacent surfaces, roofs and other sources of available water

Retention for later on-site capillary irrigation

Improved urban flood mitigation and improved urban cooling capacity

Improved; due to rainwater stored in sub-surface tank

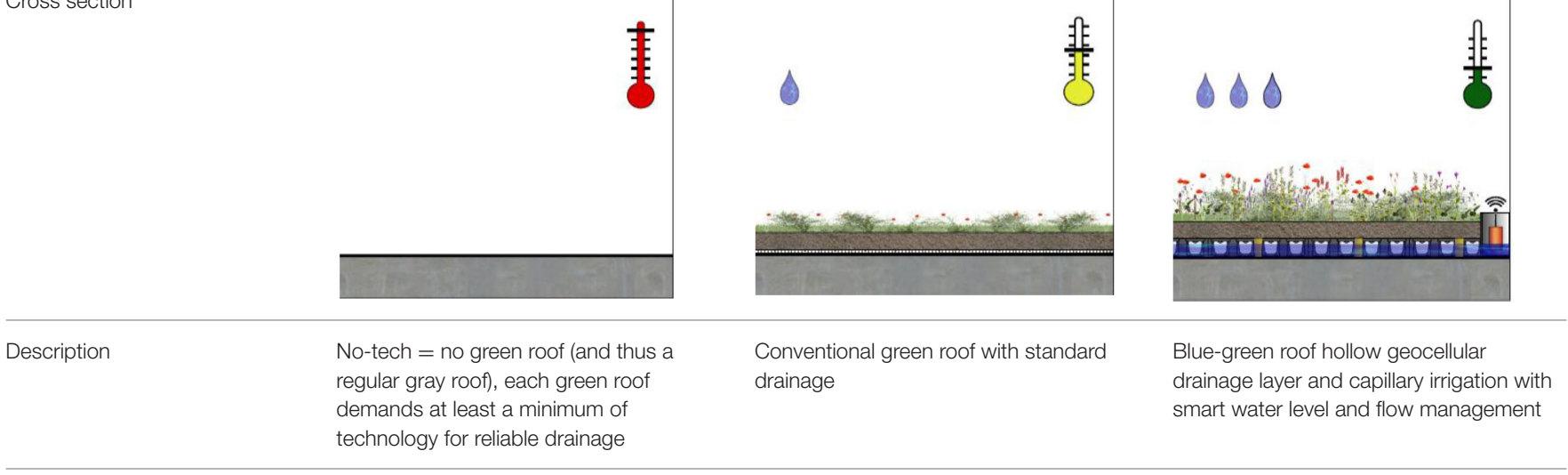


TABLE 1 | Continued

\begin{tabular}{|c|c|c|}
\hline No-tech & Low-tech & High-tech \\
\hline Precipitation retention/detention & $\begin{array}{l}\text { Limited water detention and retention in } \\
\text { vegetated areas }\end{array}$ & $\begin{array}{l}\text { Supply and demand are balanced with } \\
\text { optional weather-data controlled } \\
\text { maximized Smart water detention and } \\
\text { retention }\end{array}$ \\
\hline Climate change mitigation effect & $\begin{array}{l}\text { Limited water detention when at capacity. } \\
\text { Limited urban cooling during prolonged } \\
\text { periods of drought }\end{array}$ & $\begin{array}{l}\text { Continuous urban cooling due to reliable } \\
\text { water availability. Active and pre-emptive } \\
\text { water level management maximizing } \\
\text { retention capacity for peak rain events }\end{array}$ \\
\hline Drought resilience & Limited & $\begin{array}{l}\text { High: easy to irrigate through capillary } \\
\text { irrigation drainage layer. Accepts other } \\
\text { sources of irrigation water (i.e., HVAC } \\
\text { condensate, other roof surfaces, } \\
\text { hardscape washdown). Smart water } \\
\text { management monitors water level and soil } \\
\text { moisture content to prevent drought to } \\
\text { keep plant growth and evapotranspiration } \\
\text { at maximum level }\end{array}$ \\
\hline Biodiversity & $\begin{array}{l}\text { Depending on climate, often limited to } \\
\text { succulent plants }\end{array}$ & $\begin{array}{l}\text { All suitable plants for that region can be } \\
\text { grown since water no longer is a growth } \\
\text { limiting factor }\end{array}$ \\
\hline
\end{tabular}

Visuals: raindrops indicate retention capacity, the thermometer indicates urban cooling performance during heat wave.

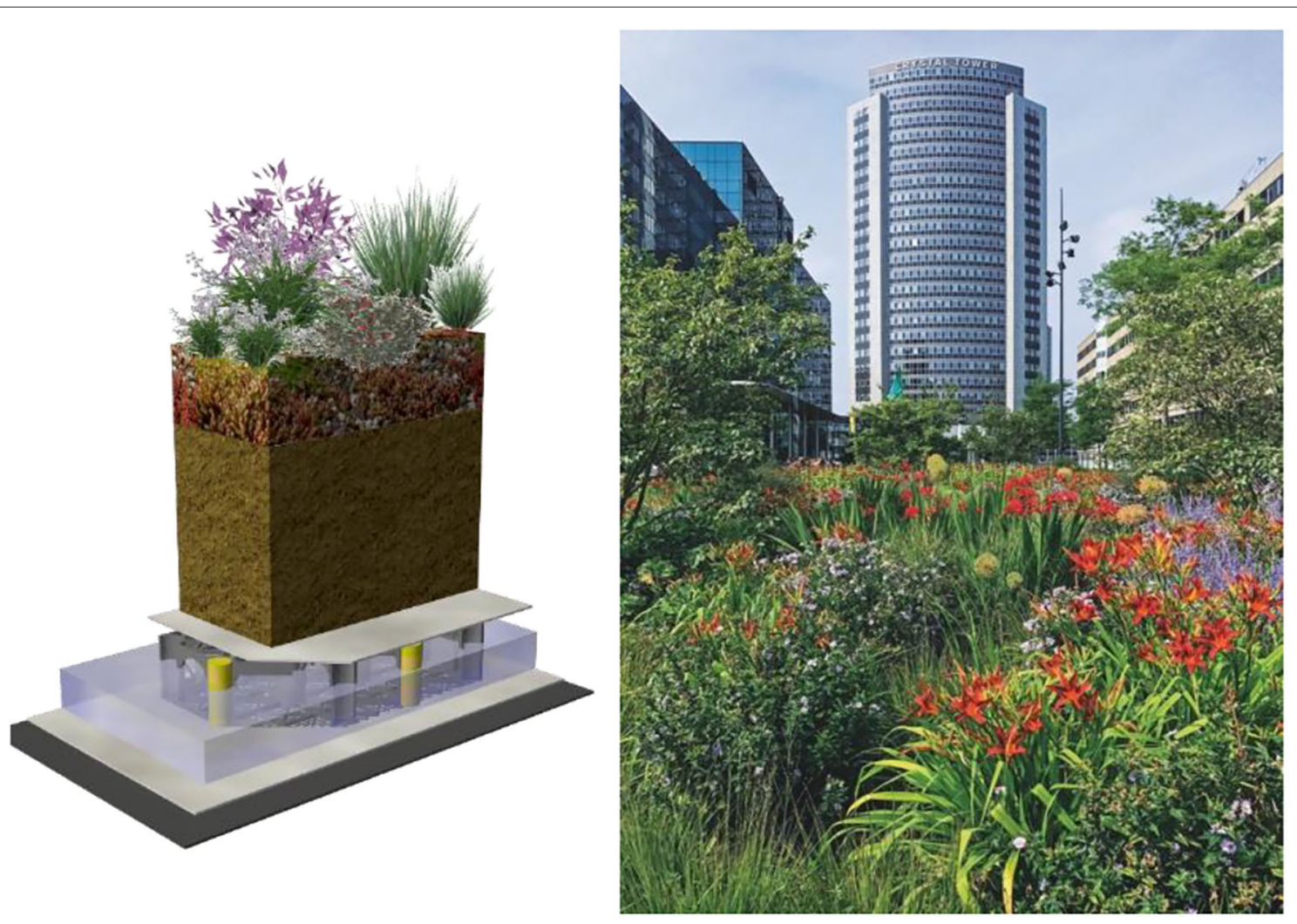

FIGURE 2 | Example of low-tech NBS: cross section of the blue-green build-up of Roofpark Orly Square, Amsterdam, Netherlands (Left) and application: the rich flowering vegetation as a result of sub-surface rainwater retention and capillary irrigation (Right).

sub-surface retention and capillary irrigation system and is based on passive overflows, thus classifies as a low tech solution (Figure 2). The transformation from gray-to-green not only improved local water management, biodiversity and wellbeing, but also positively affected the use of the surrounding real estate. Hotels surrounding the square have expanded, new shops have 
been established and new tenants now occupy the former empty offices (Bosman, 2015).

IJburg Island: For the new man-made IJburg Island in Amsterdam a tree-lined central square was created and planted with 32 oak trees. With groundwater at unattainable depths for the trees, a Permavoid geocellular system capable of storing, conveying and capillary replenishing soil moisture was placed at 1 meter depth. In the planned dense urban environment the prerequisite for the design is to sustain healthy growth and maximum evaporative cooling, without using drinking water for irrigation, or discharging surplus rainwater in sewers at any time of the year. This is achieved by harvesting extra rainwater from the adjacent $1.200 \mathrm{~m}^{2}$ school roof and infiltrating precipitation surplus back down to deep groundwater levels. An intelligent water-management system controls rainwater detention for deep infiltration in winter and rainwater retention and capillary irrigation in summer, classifying the water sensitive design as high tech (Figure 3).

\section{NEXT STEPS: THE GROWING SIGNIFICANCE OF SMART VEGETATED ROOFS AND CITY TREES FOR RESILIENT, LIVEABLE CITIES}

Since 2000 a rapid evolution in NBS has taken place in the urban greening industry. Vegetation supporting systems have evolved from "volumes of soil and lots of space" (no-tech) to systems that passively detain rainwater for later infiltration or evaporation (low-tech). In light of the growing need for circular on-site water management and climate resilience these systems have been succeeded with actively controlled retention systems, improving plant performance, while capable of absorbing supplemental sources of water for plant evaporation and harvesting water for other uses outside the green space, such as toilet flushing (Fletcher et al., 2015; Arden and Ma, 2018). And now with sensor-managed and weather data pre-emptive control of water

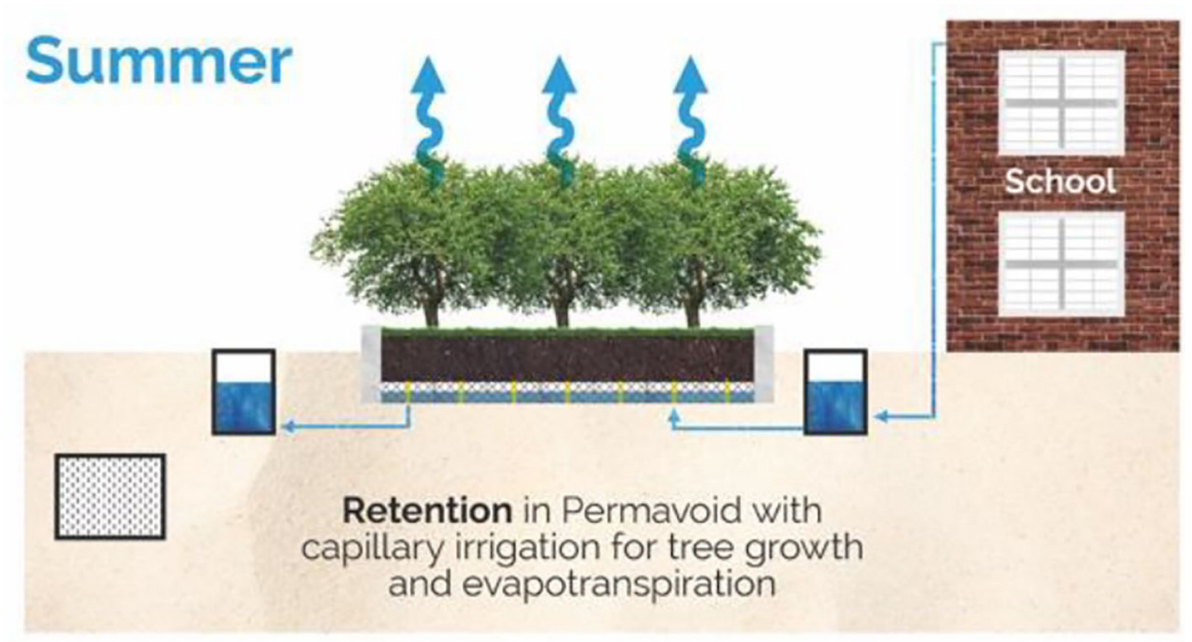

\section{Winter}

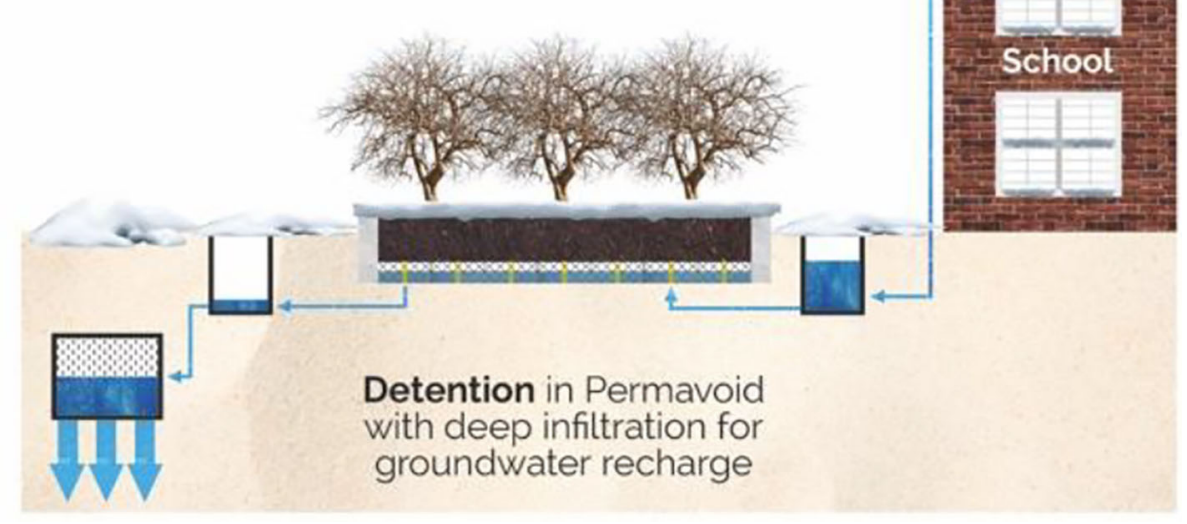

FIGURE 3 | Example high-tech NBS: Schematic overview of the smart combination of seasonally dependent retention and detention functionality made possible with smart water management at IJburg Island, Amsterdam, Netherlands. In this design Permavoid is the hollow sub-surface water retention and capillary irrigation system underneath the rootzone of the trees. 
levels, these new high-tech NBS fit seamlessly in the fabric of SMART cities.

So with vegetated roofs, city trees and other NBS's getting increasingly smarter, we encourage new front-running cities and urban projects to inspire the world with their large-scale applications of smart NBS. We foresee a future in which meeting specific performance indicators rather than visual quality alone will be required for the implementation of NBS in urban planning and design (Naddeo et al., 2020). Also, we expect resilience authorities to integrate quantitative and real time data on constructed smart NBS in their urban water management models and monitoring systems of the project area. To develop and maintain these smart high-tech NBS a new profession of the eco-engineer will emerge, demanding a mix of plant and technical knowledge (similar to smart agriculture).

By enriching the urban development jargon with our simple classification of no-, low and high-tech green we think the debate on whether or not to implement NBS will shift further into what specific NBS to implement to best fit the local demand. By doing so, the potential of NBS to strengthen the physical, social and economic functioning of cities (e.g., Raymond et al., 2017) will be used optimally. The introduction of the classification intends to teach architects, technicians and city officials that not every vegetated system offers equal ecosystem services. By indicating that in different urban environments different levels of vegetation and water management supporting technology are necessary to attain the specified ecosystem services, it should become easier to understand for professionals involved in urban planning and the building industry why the required investments justifiable

\section{REFERENCES}

Arden, S., and Ma, X. (2018). Constructed wetlands for greywater recycle and reuse: a review. Sci. Total Environ. 630, 587-599. doi: 10.1016/j.scitotenv.2018.02.218

Bai, X., Dawson, R.J., Urge-Vorsatz, D., Delgado, G.C., Salisu Barau, A., Dhakal, S., et al. (2018). Six research priorities for cities and climate change. Nature 555, 23-25. doi: 10.1038/d41586-01802409-z

Bosman, M. (2015). De Menselijke Maat op het Orlyplein - projectbeschrijving. Orlyplein. Amsterdam. Available online at: https://www.gebiedsontwikkeling. $\mathrm{nu} /$ artikelen/de-menselijke-maat-op-het-orlyplein-projectbeschrijvingorlyplein-amsterdam/ (accessed November 2020).

Brown, R., Keath, N., and Wong, T. (2009). Urban water management in cities: historical, current and future regimes. Water Sci. Tech. 59, 847-855. doi: 10.2166/wst.2009.029

Cascone, S., Catania, F., Gagliano, A., and Sciuto, G. (2018). A comprehensive study on green roof performance for retrofitting existing buildings. Build. Environ. 136, 227-239. doi: 10.1016/j.buildenv.2018.03.052

Cirkel, D.G., Voortman, B.R., Van Veen, T., and Bartholomeus, R.P. (2018). Evaporation from (Blue-)green roofs: assessing the benefits of a storage and capillary irrigation system based on measurements and modeling. Water 10:1253. doi: 10.3390/w10091253

Davies, C., and Lafortezza, R. (2019). Transitional path to the adoption of nature-based solutions. Land Use Policy 80, 406-409. doi: 10.1016/j.landusepol.2018.09.020

Depietri, Y., and McPhearson, T. (2017). "Integrating the grey, green, and blue in cities: nature-based solutions for climate change adaptation and risk reduction," in Nature-Based Solutions to Climate Change Adaptation in Urban Areas, Kabisch, N., Korn, H., Stadler, J. and Bonn, A., eds, (Cham:Springer), 91-109. doi: 10.1007/978-3-319-56091-5_6 differ between no-, low- and high tech, and that these systems are not interchangeable if the specified level of ecosystem service performance is required.

\section{DATA AVAILABILITY STATEMENT}

The original contributions presented in the study are included in the article/supplementary materials, further inquiries can be directed to the corresponding author/s.

\section{AUTHOR CONTRIBUTIONS}

RS and JV developed the idea, outline and main text for this article. GM and TV contributed with valuable comments and text additions. The article was finalized in close collaboration among the four authors. All authors contributed to the article and approved the submitted version.

\section{FUNDING}

This publication is funded by the Dutch Foundation TKI Horticulture and its partners, and the Wageningen University Knowledge Base programme: KB36 Biodiversity in a Nature Inclusive Society (project number KB36-003-008)-that is supported by finance from the Dutch Ministry of Agriculture, Nature and Food Quality. The paper builds upon earlier work on water smart cities, nature-based solutions and urban ecosystems in the Green Climate Solutions and Green Cities programmes at Wageningen Environmental Research (part of WUR).
Dorst, H., van der Jagt, A., Raven, R., and Runhaar, H. (2019). Urban greening through nature-based solutions - key characteristics of an emerging concept. Sust. Cities Soc. 49:101620. doi: 10.1016/j.scs.2019.101620

Eggermont, H., Balian, E., Azevedo, J. M. N., Beumer, V., Brodin, T., Claudet, J., et al. (2015). Nature-based solutions: new influence for environmental management and research in Europe. GAIA 24, 243-248. doi: 10.14512 /gaia.24.4.9

European Green Capital. (2019). Available online at: http://ec.europa.eu/ environment/europeangreencapital

Faivre, N., Fritz, M., Freitas, T., de Boissezon, B., and Vandewoestijne, S. (2017). Nature-based solutions in the EU: innovating with nature to address social, economic and environmental challenges. Environ. Res. 159, 509-518. doi: 10.1016/j.envres.2017.08.032

Fletcher, T. D., Shuster, W., Hunt, W. F., Ashley, R., Butler, D., Arthur, S., et al. (2015). SUDS, LID, BMPs, WSUD and more-the evolution and application of terminology surrounding urban drainage. Urban Water J. 12, 525-542. doi: 10.1080/1573062X.2014.916314

Frantzeskaki, N. (2019). Seven lessons for planning nature-based solutions in cities. Environ. Sci. Policy 93, 101-111. doi: 10.1016/j.envsci.2018.12.033

Greenroofs.com. (2019). Available online at: http://www.greenroofs.com/2018/ 06/13/portland-adopts-a-green-roof-requirement-in-the-central-city-2035plan/ (accessed May 2019).

Hansen, R., Frantzeskaki, N., McPhearson, T., Rall, E., Kabisch, N., Kaczorowska, A., et al. (2015). The uptake of the ecosystem services concept in planning discourses of European and American cities. Ecosyst. Serv. 12, 228-246. doi: 10.1016/j.ecoser.2014.11.013

Hartig, T., and Kahn, P.H. (2016). Living in cities, naturally. Science, 352, 938-940. doi: $10.1126 /$ science.aaf3759

Hattum, T., van, Blauw, M., Bergen Jensen, M., and de Bruin, K. (2016). Towards Water Smart Cities - Climate Adaptation Is a Huge Opportunity to Improve the Quality of Life in Cities. Wageningen: Wageningen University \& Research. 
Kabisch, N., Frantzeskaki, N., Pauleit, S., Naumann, S., Davis, M., Artmann, M., et al. (2016). Nature-based solutions to climate change mitigation and adaptation in urban areas: perspectives on indicators, knowledge gaps, barriers, and opportunities for action. Ecol. Soc. 21:39. doi: 10.5751/ES-08373210239

Lafortezza, R., Chen, J., Konijnendijk van den Bosch, C., and Randrup, T.B. (2017). Nature-based solutions for resilient landscapes and cities. Environ. Res. 165, 431-441. doi: 10.1016/j.envres.2017.11.038

MacKinnon, K., Sobrevila, C., and Hickey, V. (2008). Biodiversity, Climate Change and Adaptation; Nature-Based Solutions from the World Bank Portfolio. Washington, DC: The International Bank for Reconstruction and Development/THE WORLDBANK.

Maes, J., and Jacobs, S. (2017). Nature-based solutions for Europe's sustainable development. Conserv. Lett. 10, 121-124. doi: 10.1111/conl.12216

McDonald, R., and Shemie, D. (2014). Urban water blueprint: mapping conservation solutions to the global water challenge. Nat. Conser, (Washington, DC).

Mekonnen, M. M., and Hoekstra, A. Y. (2016). Four billion people facing severe water scarcity. Sci. Adv. 2:e1500323. doi: 10.1126/sciadv.1500323

Mussinelli, E., Tartaglia, A., Bisogni, L., and Malcevschi, S. (2018). The role of Nature-Based Solutions in architectural and urban design. J. Technol. Architect. Environ. 116-123. doi: 10.13128/Techne-22112

Naddeo, V., Balakrishnan, M., and Choo, K. W. (2020). "Frontiers in water-energy-nexus - nature-based solutions, advanced technologies and best practices for environmental sustainability," in Proceedings of the 2nd Waterenergynexus Conference, November 2018, Salerno, Italy. Advances in Science, Technology \& Innovation. Cham: Springer. doi: 10.1007/978-3-03013068-8

Nesshöver, C., Assmuth, T., Irvine, K.N., Rusch, G. M., Waylen, K.A., Delbaere, B., et al. (2016). The science, policy and practice of nature-based solutions: An interdisciplinary perspective. Sci. Total Environ. 579, 1215-1227. doi: 10.1016/j.scitotenv.2016.11.106

Nikolaidis, N.P., Kolokotsa, D., and Banwart, S.A. (2017). Nature-based solutions: business. Nature 543:15. doi: 10.1038/543315d

Parker, J., and Simpson, G.D. (2018). Public green infrastructure contributes to city livability: a systematic quantitative review. Land 7:161. doi: 10.3390/land7040161

Pataki, D.E., Carreiro, M.M., Cherrier, J., Grulke, N.E., Jennings, V., Pincetl, S., et al. (2011). Coupling biogeochemical cycles in urban environments: ecosystem services, green solutions, and misconceptions. Front. Ecol. Environ. 9, 27-36. doi: 10.1890/090220

Raymond, C.M., Frantzeskaki, N., Kabisch, N., Berry, P., Breil, M., Nita, M.R., et al. (2017). A framework for assessing and implementing the co-benefits of nature-based solutions in urban areas. Environ. Sci. Pol. 77, 15-24. doi: 10.1016/j.envsci.2017.07.008

Skinner, C. (2006). Urban density, meteorology and rooftops. Urban Policy Res. 24, 355-367. doi: 10.1080/08111140600876976

Solcerova, A., Van de, V. F., Wang, M., Rijsdijk, M., and van de, G. N. (2017). Do green roofs cool the air? Build. Environ. 111, 249-255. doi: 10.1016/j.buildenv.2016.10.021

Sutton, R. K. (2015). "Introduction to green roof ecosystems," in Green Roof Ecosystems, ed R. K. Sutton (Basel: Springer), 1-25. Available online at: https:// link.springer.com/chapter/10.1007/978-3-319-14983-7_1 (accessed May 15, 2020).

Urban Climate Change Research Network (2018). The Future We Don't Want: How Climate Change Could Impact The World's Greatest Cities, Technical Report, New York, NY. Available online at: http://c40-production-images. s3.amazonaws.com/other_uploads/images/1789_Future_We_Don't_Want_ Report_1.4_hi-res_120618.original.pdf

Van de Ven, F. H. M., Snep, R. P. H., Koole, S., Brolsma, R., Brugge, R., Spijker, J., et al. (2016). The Adaptation Planning Support Toolbox: providing decisionmakers with measurable output on the adaptation performance of urban design choices. Environ. Sci. Policy 66, 427-436. doi: 10.1016/j.envsci.2016.06.010

Wong, N.H., Wong, S.J., Lim, G.T., Chui, O., and Angelia, S. (2005). Perception study of building professionals on the issues of green roof development in Singapore. Arch. Sci. Rev. 48, 205-214. doi: 10.3763/asre.2005.4827

Conflict of Interest: The authors declare that the research was conducted in the absence of any commercial or financial relationships that could be construed as a potential conflict of interest.

Copyright (C) 2020 Snep, Voeten, Mol and Van Hattum. This is an open-access article distributed under the terms of the Creative Commons Attribution License (CC BY). The use, distribution or reproduction in other forums is permitted, provided the original author(s) and the copyright owner(s) are credited and that the original publication in this journal is cited, in accordance with accepted academic practice. No use, distribution or reproduction is permitted which does not comply with these terms. 